\title{
Antibiotic prophylaxis for cardiac surgery: current United Kingdom practice
}

\author{
G W Parry, S R Holden, F P Shabbo
}

\begin{tabular}{|c|c|}
\hline $\begin{array}{l}\text { Department of } \\
\text { Cardiothoracic } \\
\text { Surgery, Brook } \\
\text { General Hospite } \\
\text { London } \\
\text { G W Parry } \\
\text { S R Holden } \\
\text { F P Shabbo }\end{array}$ & \\
\hline $\begin{array}{l}\text { Correspondence to: } \\
\text { Mr Parry, FRCS, } \\
\text { Department of } \\
\text { Cardiothoracic Surg } \\
\text { Brook General Hos } \\
\text { Shooters Hill Road, } \\
\text { SE18 4LW. }\end{array}$ & $\begin{array}{l}\text { gery, } \\
\text { pital, } \\
\text {, London }\end{array}$ \\
\hline $\begin{array}{l}\text { Accepted for public } \\
29 \text { July } 1993\end{array}$ & \\
\hline $\begin{array}{l}\text { Table } 1 \text { Use of si } \\
\text { agent antibiotics fo } \\
\text { prophylaxis in card } \\
\text { surgery in adults }\end{array}$ & \\
\hline Antibiotic & No (\%) \\
\hline $\begin{array}{l}\text { Cephalosporins: } \\
\text { Cephradine } \\
\text { Cephamandole } \\
\text { Cephazolin } \\
\text { Cefotaxime } \\
\text { Cefuroxime }\end{array}$ & $\begin{array}{l}2(6) \\
2(6) \\
2(6) \\
3(8) \\
6(17)\end{array}$ \\
\hline $\begin{array}{l}\text { Penicillins: } \\
\text { Benzylpenicillin } \\
\text { Amoxycillin/amp }\end{array}$ & $\underset{\text { icillin }}{2(6)}$ \\
\hline Flucloxacillin & $\begin{array}{l}3(8) \\
5(14)\end{array}$ \\
\hline $\begin{array}{l}\text { Aminoglycosides: } \\
\text { Vancomycin } \\
\text { Netilmicin } \\
\text { Gentamicin }\end{array}$ & $\begin{array}{l}2(6) \\
2(6) \\
6(17)\end{array}$ \\
\hline
\end{tabular}

Table 2 Use of combination antibiotics in prophylaxis in cardiac surgery in adults

\begin{tabular}{|c|c|}
\hline ntibiot & 10 \\
\hline \multicolumn{2}{|c|}{ Two-agent combinations: } \\
\hline sporin + & $8(1)$ \\
\hline & \\
\hline & \\
\hline & \\
\hline & \\
\hline \multicolumn{2}{|c|}{$\begin{array}{l}\text { Three-agent combinations: } \\
\text { Penicillin + penicillin }+\end{array}$} \\
\hline $\begin{array}{l}\text { Penicillin + } \\
\text { aminoglycoside } \\
\text { aminoglycoside }\end{array}$ & \\
\hline
\end{tabular}

\begin{abstract}
A questionnaire was sent to 120 United Kingdom cardiac surgeons to ask for information on their use of prophylactic antibiotics in adult cardiac surgical patients. Data on type and duration of antibiotic were specifically sought. The response rate was $91 \%$. All respondents used prophylactic antibiotics: $32 \%$ used single agents (second and third generation cephalosporins were the most commonly used) and $68 \%$ used either two $(89 \%)$ or three $(11 \%)$ antibiotics in combination. The total duration of prophylactic antibiotic treatment was less than 48 hours for $89 \%$ of respondents. Single dose antibiotics were used by only $6 \%$.

The use of prophylactic antibiotics has changed in the past few years, with a trend away from combinations of antibiotics to single agents. The duration of use of antibiotics has shortened and the use of single dose agents has increased.
\end{abstract}

(Br Heart f 1993;70:585-586)

Since studies in the 1960s showed that use of prophylactic antibiotics reduced subsequent wound infection rates, ${ }^{12}$ prophylactic antibiotics have routinely been used in cardiac surgery. The choice of antibiotic changed as more agents became available and as understanding of the microbiology of postoperative infection improved. The duration of antibiotic prophylaxis is another important factor.

We have reviewed prophylactic antibiotic use for cardiac surgery in adults in the United Kingdom for the first time since $1986 .{ }^{3}$

Methods

A simple questionnaire (figure) was sent to 120 United Kingdom cardiac surgeons who

Questionnaire sent to 120 cardiac surgeons in the United Kingdom.

Please indicate your current policy on antibiotic prophylaxis in elective adult cardiac surgery by completing the table below

\begin{tabular}{|l|l|l|l|}
\hline & Antibiotic(s) and dose & Commenced $^{*}$ & Duration \\
\hline Valve surgery & & & \\
\hline Coronary artery bypass surgery & & & \\
\hline
\end{tabular}

^For example, with induction or preoperatively.
Table 3 Duration of antibiotic use

\begin{tabular}{lr}
\hline Duration & No (\%) \\
\hline Single dose & $7(6)$ \\
Until removal of chest drains & $33(28)$ \\
Until removal of central venous lines & $8(6)$ \\
Total duration of antibiotic use: & \\
$24 \mathrm{~h}$ & $30(27)$ \\
$48 \mathrm{~h}$ & $21(19)$ \\
$72 \mathrm{~h}$ & $6(5)$ \\
$4-5$ days & $2(1 \cdot 8)$ \\
$>5$ days & $2(1 \cdot 8)$ \\
\hline
\end{tabular}

were identified from records held by the Society of Cardiothoracic Surgeons. The response of each of the units was recorded separately but the questionnaire remained anonymous. Non-responders were not followed up and the study was closed six months after the questionnaires were sent out. We asked for data about adult cardiac surgical practice, excluding cardiac transplantation.

\section{Results}

The overall response rate was $91 \%$. All respondents used antibiotic prophylaxis for cardiac surgery in adults. Single agents were used by $32 \%$ of respondents (table 1 ) and combinations of agents were used by $68 \%$ (two agents in $89 \%$ and three agents in $11 \%$ ) (table 2). Antibiotics, whether as single agents or in combination, were stopped within 48 hours of surgery by $80 \%$ of respondents (table 3 ).

\section{Discussion}

There is clear evidence that prophylactic antibiotics can significantly reduce rates of postoperative wound infection. ${ }^{124}$ Indeed several double blind studies with placebo were stopped on ethical grounds because infection rates in the placebo groups were unacceptably high. ${ }^{45}$

Cardiac surgery is essentially a "clean" procedure and should therefore be associated with a wound infection rate of considerably less than $5 \%^{6}$; however, some studies showed wound infection rates of 6-10\% even with the use of prophylactic antibiotics. ${ }^{7}$ Many factors contribute to the development of postoperative infection and prophylactic antibiotics have no effect on most of them. These include obesity, diabetes mellitus, smoking, 
and prolonged preoperative hospital stay. Chronic obstructive pulmonary disease and prolonged cardiopulmonary bypass may also be risk factors. ${ }^{8}$ Changes in operating theatre protocol and technique can considerably alter rates of postoperative infection. ${ }^{9}$

Prophylaxis in adults should be directed against Gram positive bacteria: resistance in staphylococci has yet to become a major problem in the United Kingdom, though current trends in the United States suggest that this may change. ${ }^{10}$ In the United States vancomycin has a much greater role as a prophylactic agent because of staphylococcal resistance. Our study showed no significant increase in the use of prophylactic vancomycin since 1986 in the United Kingdom.

The selection of prophylactic antibiotic(s) should be dictated by the most likely infecting agent should a postoperative infection develop. The use of broad spectrum agents, at least in the prophylaxis of wound infection, is likely to be limited. For prophylaxis against prosthetic endocarditis in valve replacements the position is less clear: several surgeons in our study $(17 \%)$ used different antibiotics for prophylaxis in valve surgery and in coronary artery surgery.

Single agent cephalosporins are among the most effective agents in reducing infection rates in adults after cardiac surgery. ${ }^{11}$ Generally they have sufficient activity against staphylococci to be useful. Unless local microbiological conditions dictate otherwise there seems little likely benefit in adding other antistaphylococcal antibiotics, though as in 1986, this practice continues in several units.

Single agent prophylaxis with the other agents indicated in table 1 is likely to be as effective as the cephalosporins; the role of the aminoglycosides as single agents needs redefining in view of their side effects and toxicity.

Two-agent prophylaxis, though extending the antibacterial spectrum (if this is necessary) generally offers little in terms of further reduction in infection rates. A two-agent regimen remains, as in 1986, the most widely used combination. None the less since 1986 a single agent regimen has become more popular at the expense of both two and three agent combinations.

We found that three agents are not widely used for prophylaxis now and that since the previous study there had been a marked trend away from using these combinations.

Our current study showed that $80 \%$ of respondents gave prophylactic antibiotics for 48 hours or less. The duration of prophylactic antibiotic use had declined since 1986 . Only $6 \%$ of respondents used single dose prophylactic antibiotics in adults, but this was a considerable increase since the earlier study of United Kingdom practice.

In summary, we found that since 1986 there has been a greater use of single agents, less use of two and three agent combinations, and a marked trend towards using prophylactic antibiotics for $\mathbf{4 8}$ hours or less.

We thank Mr J E Dussek for the information provided by the Society of Cardiothoracic Surgeons.

1 Goodman J, Schaffner W, Collins H, Battersby E, Koenig $M$. Infection after cardiovascular surgery. $N$ Engl f Med M. Infection after

2 Fekety F, Cluff L, Sabiston D, Seidl L, Smith J, Thoburn R. A study of antibiotic prophylaxis in cardiac surgery. f Thorac Cardiovasc Surg 1969;57:757-63.

3 Wilson A, Treasure T, Sturridge $M$, Gruneburg $R$ Antibiotic prophylaxis in cardiothoracic surgery in the United Kingdom: current practice. Thorax 1986;41: 396-400.

4 Fong I, Baker C, McKee D. The value of prophylactic antibiotics in aorto-coronary bypass operations. $\mathcal{F}$ Thorac Cardiovasc Surg 1979;78:908-13.

5 Sutherland R, Martinez H, Guynes W, Miller L. Post operative chest wound infections in patients requiring coronary bypass. $\mathcal{f}$ Thorac Cardiovasc Surg 1977;73: 944-7.

6 Miedzinski L, Callaghan J, Fanning E, Gelfand E Antimicrobial prophylaxis for open heart operations. Ant Thorac Surg 1.990;50:800-7.

7 Bor D, Rose R, Modlin J, Weintraub R, Friedland G. Mediastinitis after cardiovascular surgery. Rev Infect Dis 1983;5:885-97.

8 Nagachinta T, Stephens M, Reitz B, Polk B. Risk factors for surgical wound infection following cardiac surgery f Infect Dis 1987;156:967-73.

9 Ferrazzi P, Allen R, Crupi G, Reyes I, Parenzan L Maisonnet $M$. Reduction of infection after cardiac surgery: a clinical trial. Ann Thorac Surg 1986;42:321-5.

10 Woods $M$, Tillman D. Antibiotic prophylaxis in cardiothoracic surgery 1990: results of a third survey. Hosp Pharmacy 1992;27:404-7.

11 Kreter B, Woods M. Antibiotic prophylaxis for cardiothoracic operations. $\mathcal{f}$ Thorac Cardiovasc Surg 1992;104: 590-9. 